\title{
Provincia ARmenia in the Light of the EPIGRAPHiC EVIDENCE $^{1}$
}

\author{
Michael Alexander Speidel \\ iD http:/orcid.org/0000-0003-2201-6567 \\ Universities of Warsaw and Zürich
}

\begin{abstract}
One very prominent context of the Pre-Christian history of Armenia of course lies with its relations with the great neighbouring empires of Parthia and Rome. These relations were mainly the result of Armenia's geopolitical location between the two empires, its natural resources and its control of strategic long-distance routes. From a Roman point of view, Armenia certainly was the most important geopolitical concern in the East. Roman-Armenian relations therefore are a vast and complex subject, and their history extends over many centuries. In the years between 114 and 117 AD these relations assumed an extraordinary albeit short-lived condition when the kingdom of Greater Armenia became a Roman province. The present contribution reviews the Roman inscriptions that can be dated to this period, as well as the historical evidence they provide for the history of Greater Armenia as a Roman province.
\end{abstract}

Keywords: Armenia, Trajan, Roman History, Latin Epigraphy.

\section{Provincia Armenia maior's new Roman Government}

In the spring of 114 at Elegeia, the imperial base in Armenia, the Roman emperor Trajan declared to the surprise of the Armenian king and his followers that he "would surrender Armenia to no one, for it belonged to the Romans and was to have a Roman governor" (Dio 68.20.3). After a swift take-over of Armenia and after Trajan "won over" several kings, who "voluntarily submitted" as well as others who were "disobedient" but were

1 For earlier Roman threats to provincialize Armenia maior see RGDA 27. Tac., Ann. 15,6,1. I thank Mkrtich Zardaryan (Yerevan) for his generous hospitality during my visit to Armenia in April 2018, as well as Anahide Kéfélian (Paris / Oxford) for her kind help with finding difficult to access Armenian literature. Research for this contribution was carried out in the context of the author's fellowship no. UMO-2016/23/P/ HS3/04141 of the National Science Centre, Poland. This project has received funding from the European Union's Horizon 2020 research and innovation programme under the Marie Skłodowska-Curie grant agreement No 665778 
subdued without battle, the Roman "Senate bestowed upon him the title Optimus." This happened before 3 or 4 May 114, as a military diploma reveals. ${ }^{3}$ Around two years later, in $116 \mathrm{CE}$, the imperial mint in Rome struck a new series of coins with the legend ARMENIA ET MESOPOTAMIA IN POTESTATEM P R REDACTAE (RIC Trajan 642). This was the perhaps most conspicuous measure the imperial government took to promulgate the news among the inhabitants of the Empire of Trajan's acquisition of two new provinces. It is, of course, well-known that only very little of what this actually entailed is recorded in the surviving sources. Nearly the entire historical data concerning provincia Armenia maior and its integration into the imperial administrative and military system of Roman provincial government survives through inscriptions. ${ }^{4}$ Thus, Latin inscriptions from El Djem in Tunisia (anc. Thysdrus in Africa Proconsularis) and from Anzio (anc. Antium) in Italy reveal the name of its first and only Roman governor: Lucius Catilius Severus Iulianus Claudius Reginus (cos. suff. 110, cos. ord. 120), a man with family ties to the emperor: ${ }^{5}$

L(ucio) Cat $[i] l i o$ C[n(aei) f(ilio) Cla]u(dia) Sev[e]ro I[u]lia[no] / Claudio Reg[i]no co(n) $[s($ uli) II pr-]o[c]o(n)s(uli) provin[c(iae)] / Af[ri]cae [---]RP[---] et [---]L [l]eg(ato) Aug(usti) [pro] / [pr(aetore)] pro[v(inciae) Syriae l]eg(ato) Aug(usti) pr[o] pr(aetore) Arm[eniae] / [m]aior[is e]t $\boldsymbol{m}[$ in] $\mathbf{0 r}[$ is] et Ca[p]padoci[ae] / [p]raef(ecto) aer[a]r(ii) $m[$ ilitar(is)] leg(ato) leg(ionis) XX[II] Primi $[g($ eniae $) p($ iae $) f($ idelis $)] /[c]$ urato[ri --- le $] g($ ato $)$ pro pr(aetore) $[p] \operatorname{rov}[i] n c[$ iae $] /$ Asiae [VIvir(o) eq(uitum) R(omanorum)] pr(aetori) u[rb(ano)] [q]uaes[t(ori) prov(inciae) As]iae $d($ ecreto $) d($ ecurionum $)[p($ ecunia $)$ p(ublica $)]($ ILAfr $43=$ ILTun 109, El Djem)

[L(ucio)] Catilio Cn(ai) f(ilio) [Clau(dia)] / [Sever]o Iuliano Cl(audio) R[egi]no / co(n)s(uli) II proco (n)s(uli) provinc(iae) / Afr [ic]ae / leg(ato) Aug(usti) pro p[r(aetore) provi]nciae Syriae et pro-/vinciae Cappad[ociae] et Armeniae maior(is) / et minor(is) VIIvir(o) epu[lon(um)d]onis militaribus / donato a divo Tra[iano] corona mur[ali] / vallari navali h[astis puris IIII vexill]is IIII pr(aefecto) urb(i) / praef(ecto) aerarii Sat[urni praef(ecto) aerar(i) m]ilitar(is) leg(ato) / [leg(ionis) XXII Pri]m(igeniae) p(iae) f(idelis) cu[r(atori) --- leg(ato) prov(inciae) As]iae praef(ecto) / [frumenti] dandi e $[x$ s(enatus) c(onsulto) seviro eq(uitum) Rom(anorum) turm] ae II / [fetiali qua]est[ori pro praet(ore) provinciae] Asiae (CIL X $8291=I L S$ 1041, Antium).

Severus was appointed to the position of legatus Augusti pro praetore Armeniae maioris et minoris et Cappadociae as it says on the inscription from el Djem or, the other way round, legatus Augusti pro praetore provinciae Cappadociae et Armeniae maioris et minoris as the inscription from Anzio has it, after the conquest of Armenia early in 114 and before the emperor proceeded southwards with the expeditionary army in the winter of $114 / 115$, crossing the mountains and invading the upper valley of the Tigris. ${ }^{6}$ Severus' appointment entailed the immediate end of the double province of Cappadocia et Galatia. Galatia was now detached from Cappadocia and forthwith received governors of its own while Greater Armenia took Galatia's place at the side of Cappadocia. ${ }^{7}$ This constel-

2 Dio 68.18.3; 23.1.

3 RMD IV 226; Kienast 2017, 117.

4 Cf. however, Dio 68.20.3 with Birley 1997, 70-76 (notes 10ff.).

5 PIR ${ }^{2}$ C 558. See Eck 1982, 357-362.

6 See Birley 1997, 70-71; Marciak 2017, 373; Strobel 2019, 439.

7 Within this administrative complex, however, Armenia maior was referred to as a separate entity: cf. e.g. RIC Trajan 642; CIL IX 3427 and XI 5213. 
lation remained unchanged throughout the short period of the new province's existence: Roman Armenia maior shared the consular governor Catilius Severus with provincia Cappadocia until the Romans abandoned Greater Armenia in $117 .{ }^{8}$

The inscription from Italian Antium reveals that Lucius Catilius Severus received military decorations from Trajan, no doubt during the Parthian War. Severus probably belonged to the imperial entourage since the beginning of the campaign. Unfortunately, however, Severus' cursus honorum in the inscription from Antium does not strictly follow a chronological order. It is therefore not clear whether Severus earned these distinctions before he became governor of Cappadocia-Armenia or during that time. To be sure, some fighting had to be done in Armenia in 114. C. Bruttius Praesens, the legate of legio VI Ferrata, and his soldiers fought in the snow-covered mountains somewhere near Lake Van, where local guides supplied them with snow shoes. ${ }^{9}$ In the same year, Lusius Quietus, the Moorish prince, is also on record for having fought at the head of another division of the Roman expeditionary army (no doubt including his fellow-countrymen) against the Mardi east of Lake Van. ${ }^{10}$ Decisive Roman victories occurred in the months of September to November / December in 114 when Trajan received his $7^{\text {th }}, 8^{\text {th }}$, and $9^{\text {th }}$ imperial acclamations. ${ }^{11}$

The combat forces are most likely to have left Greater Armenia together with the imperial expeditionary army on its way to the South during or after the winter of 114 / 115 AD. The emperor left the new governor Catilius Severus together with an occupying force for Armenia behind and gave orders to secure the new provincial territory and deal with its integration into the world of the Roman Empire. It is not known which city was chosen as Severus' Armenian residence and whether he spent more time in Greater Armenia or in Cappadocia. Yet as governor of Armenia-Cappadocia and as a loyal follower, Severus apparently fully lived up to the expectations of Trajan's successor Hadrian, as he continued to be appointed to high-ranking positions after Trajan's death which even led him to the consulate, the pinnalce of the senatorial career.

It is not clear whether Trajan had been planning to appoint Lucius Catilius Severus to the governorship of Cappadocia-Armenia all along or whether he only shaped his final decision in the period before he invaded the kingdom. According to Cassius Dio, the emperor publicly, and to the surprise of those present, pronounced his decision to provincialize Armenia maior only in 114 at Elegia when he refused to give the Armenian crown back to king Parthamasiris. ${ }^{12}$ Of course he may well have made up his mind long before. However, his appointment of an equestrian financial procurator for the new province does give the impression of an $a d$ hoc ruling. This is suggested by an acephalous inscription from Italian Fulginiae (mod. Foligno in Umbria), which reveals the career

8 Cf. Dio 68 (75).9.6. In the years from 114 to 117, provincia Armenia was a reality. It is misleading, therefore, to state that Trajan "tried in vain to establish the Roman province of Armenia" or to refer to it as ,,an unsuccessful attempt to establish a Roman province of Armenia”, as in Lichtenberger et a. 2020, 184 and 197.

9 Arr., Parth. frg. 85; AE 1950, 66; Chaumont 1976, 137; Birley 1997, 70; Strobel 2019, 439.

10 Them., or. 16.250. Cf. Arr., Parth. frg. 86 and 87; Chaumont 1976, 137-138; Birley 1997, 70; Strobel $2019,439,448$.

11 Kienast 2017, 117.

12 Dio 68.20.3. 
of a procurator Augusti Armeniae maioris, who eventually rose to become prefect of Egypt. $^{13}$

- primopi]lo prae[f(ecto)] / [coh]ortis trib(uno) milit [um] / [p]raef(ecto) equit(um) censito[ri] / Brittonum Anavion[ens(ium)] / proc(uratori) Aug(usti) Armeniae mai[oris] / ludi magni hereditatium / et a censibus a libellis Aug(usti) / praef(ecto) vigilum praef(ecto) Aegyp[ti] / M(arcus) Taminius Ce[- (CIL XI $5213=$ ILS 1338 (Fulginiae)

This inscription is generally and convincingly attributed to T. Haterius Nepos, the prefect of Egypt between 120 and 124. ${ }^{14}$ Nepos began his career with the equestrian tres militiae. The third militia, as cavalry prefect, was probably coupled with the function of census-officer (censitor) of the Anavionensian Britons. A writing-tablet from Vindolanda on Hadrian's wall in Britain dating to around or just before $100 \mathrm{CE}$ can be taken to indicate Nepos's command of ala Petriana at Cordbridge, as it preserves the fragment of a letter which Haterius Nepos wrote to Flavius Genialis, the prefect of the ninth cohort of Batavians at Vindolanda. ${ }^{15}$ Nepos's task as census-officer involved registering the taxable Anavionensian Britons who are thought to have paid their obligations to Rome, at least in part, by supplying conscripts for the army. Nepos's experience in such matters may have later contributed to his appointment to the post of proc(urator) Aug(usti) Armeniae mai[oris].

In any event, after returning from Britain, Nepos retired from imperial service. Only in $114 \mathrm{CE}$ was he suddenly reactivated. In this year, Trajan needed an equestrian procurator for the financial administration of the new province of Armenia, i.e. an official, who was to be responsible for the tax collection, supplying the army, and for delivering soldiers' pay. ${ }^{16}$ Nepos' title, of proc(urator) Aug(usti) Armeniae mai[oris], shows that Greater Armenia was given its own financial administration within the framework of provincia Cappadocia et Armenia maior et minor. In other words, the fiscal administration of Armenia maior was established as an independent unit. Although Nepos evidently had some relevant experience from his time in Britain, choosing him from his state of retirement in Italy at an age of presumably well over 40 appears to betray a certain urgency in developing a comprehensive administrative structure for the new province. His appointment thus reveals Rome's firm intention to lose no time with securing the new province's fiscal resources. We can therefore safely assume that Armenians were now also forced to pay their taxes to Rome, just as they no doubt had to fight for the Empire.

Yet Nepos, the highest-ranking equestrian official in the new province, did not arrive in Greater Armenia on his own, for a financial procurator would normally have a staff that included imperial freedmen and slaves, who did most of the routine work, as well as a number of auxiliary soldiers, ${ }^{17}$ who helped to enforce prompt payment of dues when needed. None of these have left a trace in the surviving records. Unfortunately, there is also no evidence regarding the Armenian city, in which Nepos, had his administrative

13 CIL XI 5213 = ILS 1338 (Fulginiae). See Pflaum 1960-1961, no. 95.

$14 P I R^{2} \mathrm{H} 29$. For the following see esp. Birley 2005, 321-322.

15 TV III (= The Vindolanda Writing-Tablets (Tabulae Vindolandenses III), ed. by A. K. Bowman and J. D. Thomas, London 2003), 611, back: Flavio Geniaḷ / praef(ecto) coh(ortis) / ab Haterio Nepotẹ.

16 Cf. Strabo 3.4.20; Dio 53.15.3. Cf. Dio 52.25.1-3; 54.21.2-8.

17 See e.g. CIIP 2, 1287 (Caesarea Maritima). 
centre. However, considering the short life span of Roman Armenia, it is likely that Nepos was the only official ever to be appointed to the position of proc(urator) Aug(usti) Armeniae maioris. His ensuing career implies that he fulfilled his tasks in Armenia to the satisfaction of Trajan's successor Hadrian.

\section{A new legionary fortress at Artaxata (?)}

The most impressive evidence for Roman activities in provincia Armenia is a monumental Latin building inscription set up by legio IV Scythica at Artaxata, the former royal residence. This legion had its permanent base camp at Syrian Zeugma on the Euphrates but appears to have played a significant role during the short period in which Armenia was a Roman province. ${ }^{18}$ This Latin inscription dates to the second half of $116 \mathrm{CE}$ ( $A E$ 1968, 510):

Imp(erator) Caesar divi Nervae f[il(ius) N]erva Traianus / Optimus A[u]g(ustus) G[e]rm(anicus) Daci[c(us) Pa]rthicus pont(ifex) max(imus) / trib(unicia) pot(estate) XX [im]p(erator) XIII co(n)$s(u l) V I[p($ ater) $p$ (atriae) $p]$ er leg(ionem) IIII Scyt(hicam) fecit.

The inscription was found in 1965 during construction works for a canalization project at Armenian Pokr Vedi near the site of ancient Armenia's royal city of Artaxata. ${ }^{19}$ Its face measures c. $850 \times c .79 \mathrm{~cm}$ and commemorates legio IV Scythica's construction of a major edifice that was erected upon the orders of the emperor Trajan. The reading and dating have been convincingly established, but the type of building that it belonged to has not. ${ }^{20}$ It was evidently not necessary for the inscription to mention the type of construction that legio IV Scythica had built, as everyone reading the inscription could see it directly in front of them. The emperor's direct orders, the fourth legion as the responsible agent, the Latin language and the restored width of the inscription of c. 8.5 meters are all clear signs of the building's major proportions and its superior imperial significance, conveying the message of Rome's presence in Artaxata, as well as the Empire's intention to stay in Greater Armenia.

The inscription lacks a dedication to a deity or to the emperor. We can therefore safely rule out the possibility that the construction to which it once belonged was an arch or some other victory monument. ${ }^{21}$ Joyce Reynolds was not doubt right to suspect that the

18 Cf. CIL IX 3427 (Peltuinum, Italia): -] / leg(ionis) $<I>V$ Scyt(h)icae in Ar[menia - no doubt part of a senatorial or equestrian career inscription - possibly refers to the legion's mission in Armenia in 114-117 CE. See Speidel 1998, esp. 170.

19 See e.g. Arakelian 1967; Arakelian 1968; Arakelian 1971; Reynolds 1971, 141 with Plate X (correctly restoring $p($ ater $) p($ atriae) p.]er in line 3); Mitford 1974, 162; Mitford 2018, II: 553 no. 107 (wrongly asserting that 'fecit' was inserted in a fourth line under 'Scyt').

20 Arakelian 1968, 137 considered: "Fortezza, caserma, tempio, cimitero della suddetta legione (i.e. IV Scythica), o altro?" All but the first suggestion can be dismissed. Coloru 2013, 724 also suggested the best solution, "a fort," yet without further comments.

21 Mitford 1974, 162 considered it to be "part of a tropaeum." Similarly Mitford 2018, II: 553 with reference to $A E$ 1933, 225 and $C I L$ III 12467, both of which, however, bear dedications and are thus not comparable. 
building to which the inscription originally belonged, was a military one. ${ }^{22}$ At any rate, the vast majority of buildings that were constructed by the army, indeed served military purposes. $^{23}$ This was no doubt all the more true in the present case as the war was still going on when the building with its inscription was set up. ${ }^{24}$ The completion of this major building project in 116, i.e. less than two years after the conquest, even reveals a degree of urgency. ${ }^{25}$ Considering the inscription's dimensions, its significance, and its likely military nature, as well as its find spot and date, the construction may perhaps have been the gate of a military fortress. ${ }^{26}$ If true, this fortress was probably intended to serve as the new base camp of legio IV Scythica, which then was to be part of Armenia's new Roman garrison. At any rate, Cassius Dio maintains that on his way to northern Mesopotamia (i.e. through Armenia) Trajan left garrisons at strategic places. ${ }^{27}$ No doubt, Artaxata would have been a very important such place. However, we do not necessarily have to assume that the entire legionary fortress had been completed in stone by 116 . One could instead well imagine that the monumental gate was among the very first constructions of the fortress to be completed.

In any event, finds of stamped bricks and tiles of legio IV Scythica from within the ancient city of Artaxata and, apparently, from its immediate surroundings imply that the legion had more than one construction project at the former royal capital in these years, which may have included a major aqueduct for the water supply of Artaxata. ${ }^{28}$ One particular area in which stamped material was found was on Artaxata's hill no. 8. Remarkably, unpublished Latin graffiti are also reported to have been found there, on the wall of a house. ${ }^{29}$ Perhaps Roman officers and soldiers of legio IV Scythica initially moved into and renovated this quarter of the Armenian capital. Be that as it may, there is no reason to assume that the Roman authorities planned to billet the soldiers of the

22 Reynolds 1971, 141.

23 Cf. e.g. Cotton - Eck 1999; Horster 2001, 168-186.

24 Cases like CIL VIII $2355=$ CIL VIII $17842=$ ILS 6841 from Thamugadi are therefore unsuited to help understand the Artaxata inscription.

25 For such reasons it is unlikely that the inscription referred to an aqueduct for the fresh water supply of the city of Artaxata: https://armenpress.am/eng/news/1001438.html (accessed: 20.01.2020).

26 Compare, for instance, the inscription over the main gate of the 2 nd century legionary fortress at Castra Regina on the Danube: CIL III 11956 = AE 1971, 292 (Regensburg, 179 CE): [Imp(erator) Caesar divi Antonini Pii filius divi Veri Parthici Maximi] frater divi Hadriani nepos divi Traiani Pa[rthici pronepos divi] / [Nervae abnepos M(arcus) Aurelius Antoninus Aug(ustus) Germanicus Sarma]ticus pontifex maximus trib(uniciae) potestatis $X X X<I I I>i[m p($ erator $)$ VIIII co(n)s(ul) III p(ater) p(atriae) et $] /[$ Imp $(\operatorname{erator})$ Caesar M(arcus) Aurelius Commodus Antoninus Aug(ustus) Sarmat]icus Germanicus Maximus Antonini Imp(eratoris) [filius divi Pii nepos divi] / [[Hadriani pronep(os) divi Traiani Parthici abn(epos) divi Nervae adn(epos) trib(unicia) pot(estate) IIII i]mp(erator) II co(n)s(ul)] II vallum cum portis et turribus $<l>e g($ ioni $)$ I[II Italicae Concordi] / [fecerunt curante] M(arco) Helvio C[le]mente Dextriano leg(ato) Au[gg(ustorum) leg(ionis) eiusdem]. Cf. e.g. Dietz - Fischer 2018, 129 and 135. Compare also RIB 665 (York, 108 CE): [I] mp(erator) Caesar / [divi N]ervae fil(ius) Ne[rva] / [Trai]anus Aug(ustus) Ger[m(anicus) Dac] / [icus po-] ntifex maximu $[$ s tribun] / [iciae po]testatis XII imp(erator) V[I co(n)s(ul) V p(ater) p(atriae)]/[portam] per leg(ionem) VIIII Hi[sp(anam) fecit $]$.

27 Dio 68.21.1.

28 Kanetsian 1998, 68-69; Khachatryan 2006, 230-235. Aqueduct: Lichtenberger et al. 2020, 195.

29 Kanetsian 1998, 68. Cursory references to further such Latin graffiti were made by M. Zardaryan during his presentation at the conference in Münster. 
fourth legion (or any other legion for that matter) to quarters within the city as a permanent solution.

\section{Trajanic Kainepolis (?)}

Yet stamped tiles of legio $I V$ Scythica are not restricted to the site of ancient Artaxata. A further tile with a stamp of the fourth legion was recovered at Vagharshapat-Edjmiadsin. The tile was found in 1967, re-used as part of a make-shift lid of a second or early 3rd century sarcophagus. ${ }^{30}$ Although the tile is on display in the local archaeological museum and references to it can even be found in publications that are available in the West, no one, it seems, has yet contemplated the possible implications of this find ${ }^{31}$ It must be admitted that it cannot be ruled out that the tile was transported for forty or more kilometres from Artaxata to Vagharshapat. However, there is no obvious reason or likely explanation why that should have been the case. A chemical analysis might settle the matter. We can however be certain that the tile was produced in the short period of 114$117 \mathrm{CE}$, in which legio IV Scythica was involved in construction projects in Armenia. If the tile was indeed produced for a local military construction at Vagharshapat, as seems likely, it would add credence to the claim of Movses Chorenats'i (Mos. Chor. II 65), that it was king Valarsh I who founded Valarshapat and called it „New Town“. If true, Kainepolis was not a new foundation of the 160 s as is generally held but may rather have had its roots in Trajan's short-lived provincia Armenia, where the Emperor may have established one of the strategic strongholds that Cassius Dio mentioned. ${ }^{32}$

\section{Legio IV Scythica felix operosa}

The many stamped bricks and tiles that legio IV Scythica produced in Armenia are practically identical to those from Northern Syria and shed light on the role of the fourth legion during the short period in which Armenia was being integrated into the provincial system of the Roman Empire (114-117). For the bricks, tiles and the building inscription from Artaxata show that the fourth legion was predominantly involved in constructing the new province's infrastructure. ${ }^{33}$ In this, Trajan appears to have given legio IV Scythica a role in Armenia in 114 that was comparable to the one he gave legio IV Flavia in Dacia and legio III Cyrenaica in Arabia, both in 106. These two legions were also deployed as main builders in their new Trajanic provinces. Thus, tiles bearing the stamp of legio IIII Flavia felix have been discovered in more than twenty settlements in Dacia, including colonia Ulpia Traiana Dacica Sarmizegetusa and five or six auxiliary forts. ${ }^{34}$ In Arabia, soldiers of legio III Cyrenaica were involved in construction activities at Petra, Bostra,

30 Khachatryan 2006, 230. As yet, this remains a single isolated find.

31 E.g. Kanetsian 1998, 68.

32 See above note 28.

33 Cf. Crow 1986, 80.

34 Glodariu 1966, 431-432; Piso 2000, 211. 
Hegra and other sites. ${ }^{35}$ It seems likely, therefore, that legio IV Scythica, too, was involved in construction projects at various sites in Armenia.

In fact, there was nothing accidental about choosing legio IV Scythica for such tasks in Armenia in 114, for this legion was employed for an unusual number of construction projects even at her permanent base at Zeugma and its surroundings as well as in other parts in the North of provincia Syria. ${ }^{36}$ That is evidenced by the great many building inscriptions and stamped tiles of the fourth legion found in Northern Syria. It is especially highlighted by a very unusual early Vespasianic (?) inscription from a small quarry at a hamlet called Habeş on the Euphrates some kilometres upstream from Zeugma, where soldiers of legio IV Scythica had been involved in building a bridge. For in this inscription, the legion was styled operosa felix, "the hard-working, fortunate." ${ }^{37}$ These were not official parts of the legion's name, but they do echo official titles. The title felix, not previously found among the legion's epithets, referred to success on the battlefield. The emperor Vespasian was the first to award it to legions. ${ }^{38}$ But of course, the epithet felix has no apparent relevance in the context of quarry-work. And no other legion is known to have ever been called operosa. In fact, working in quarries was particularly unpopular with most soldiers, for cutting stones under the hot Near Eastern sun was hard and dangerous. ${ }^{39}$

From the quarry at Arulis in the Euphrates valley, only a few kilometers north of Zeugma, two new inscriptions cut into the face of the rock have recently been discovered. ${ }^{40}$ However, their published readings can be improved to further illustrate the heavy involvement of legio IV Scythica's soldiers in construction works in these years. According to the published photographs, the first inscription ( $A E$ 2015, 1669, Arulis) can be improved from SCYT FEL to: ${ }^{41}$

\section{LEG IIII SCYT FEL}

The published photograph of the second inscription ( $A E 2015,1668$, Arulis) suggests not LEG IIII / FF as the editor proposed, but the reading: ${ }^{42}$

\section{LEG IIII $S$}

FEL

It is remarkable that all three inscriptions known to call legio IV Scythica felix, "fortunate," are from quarries. If this is not a mere coincidence (which it may well be), it raises questions. Had calling the fourth legion felix in quarries become a running joke? Or did the soldiers who worked in quarries and on building sites consider their legion fortunate, felix, to have escaped the imponderabilia and dangers of the battlefield? The latter is perhaps less likely, for soldiers of legio IV Scythica did in fact, fight on the battle fields

35 Cf. Speidel, forthcoming.

36 Speidel 1998, 168-175.

37 AE 2001, 1956. Speidel 2009, 249-253.

38 Speidel 2009, 250-253.

39 Cf. e.g. P.Mich. 465; 466; Speidel 2009, 251.

40 Albustanlığlu 2015.

41 See Albustanlığlu 2015, resim 14.

42 See Albustanlıoğlu 2015, resim 12. The photograph is not clear enough to show whether further letters follow the $\mathrm{S}$ in line 1 . 
of Trajan's Parthian war, and a young officer even earned military decorations. ${ }^{43}$ Nevertheless, legio IV Scythica's reputation included an extraordinary track record in the field of quarrying and construction work, and in the light of the surviving sources it is above all else in this role that it made an impact on the short history of provincia Armenia. This has perhaps not so far been fully appreciated. ${ }^{4}$

Be that as it may, if legio IV Scythica was indeed chosen to belong to Greater Armenia's new military garrison, we also need to understand its local building activities with regard to the many members and followers that this legion brought into the former kingdom. We can thus assume that together with over 5'000 Roman citizen soldiers and five equestrian military tribunes at least two Roman Senators, one of praetorian rank (the legatus legionis) and a younger man in his early twenties (the tribunus laticlavius) moved to new base of operations at Artaxata. With them came many others, including families, friends, suppliers and people who hoped to do business with the Roman soldiers and officers. Even if many members of the legion may have been on duty elsewhere in the new province, the presence of the fourth legion no doubt had a major impact on the daily life at Artaxata in the years from 114 to $117 \mathrm{CE}$. Moreover, other equestrian officers also moved to various places in Greater Armenia at the head of their mostly c. 500 strong auxiliary alae and cohortes. Some of these soldiers may have joined the staff of the procurator Armeniae minoris.

\section{Other Legions}

Yet legio IV Scythica is not the only Roman legion attested epigraphically in provincia Armenia during Trajan's Parthian war. The gravestone from Pokr Vedi of a soldier who served with a detachment of legio I Italica provides further information. Broken into many fragments, this stele was found together with the monumental building inscription of legio IV Scythica and is therefore probably best understood to have originally stood in some association with that monument. It would indeed be fitting if the find spots of these two inscriptions stood in approximate vicinity to their original location, for soldiers' graveyards are regularly found outside the gates of military fortresses. Between 1967 and 1971, Babken Arakelyan published both inscriptions in Armenian, Russian and Italian in different journals, some of which included translated abstracts in other languages. ${ }^{45}$ All publications included the same photograph and drawing of the gravestone, as well as a transcription of the inscribed text and a commentary: ${ }^{46}$

43 CIL III 10336 = ILS 1062 (Székesfehérvár); PIR² C 933-934; Devijver 1998, 214, no. 14.

${ }^{4}$ Cf. e.g. Strobel 2019 without mentioning legio IV Scythica's presence in Armenia during Trajan's Parthian war.

45 Arakelian 1967; Arakelian 1968; Arakelian 1971.

46 The transcriptions of the inscription in the three publications differed almost exclusively in the types of brackets employed. The transcription given here is the one from VDI in 1971. 


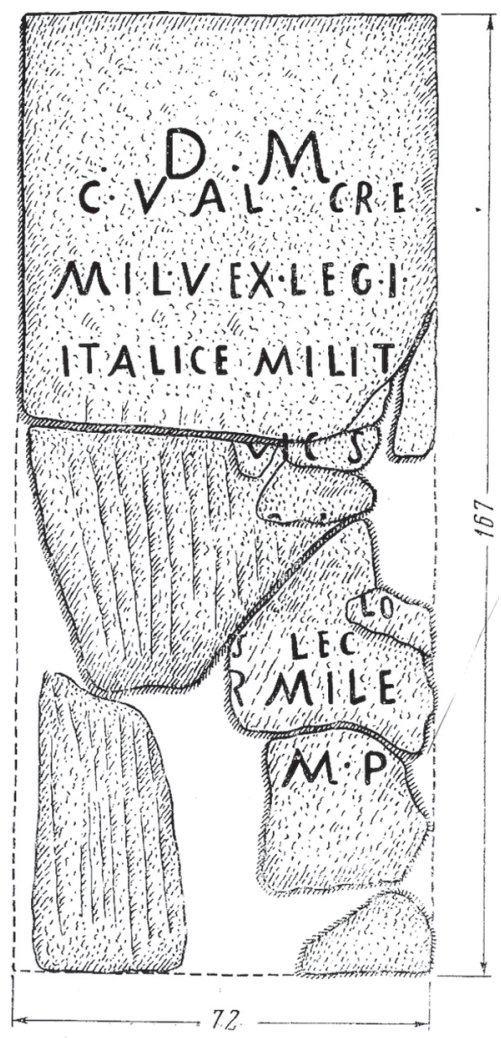

Рис. 3. Прорисовка надписи на надгробии римского легионера

Arakelian 1971, fig. 3.

1. D(IS) M(ANIBUS)

2. C(AIUS) VAL(ERIUS) CRE[...]

3. MIL(ES) VEX(ILLATIONIS) LEG(IONIS) I

4. ITALIC[A]E MILI(AVIT)

5. ---------

6. ---------

7. ----------

8. ---------

9. ---------

10. M . . .... P(OSUERUNT)

Remarkably, however, this was not the text which was registered by Western scholarship. Drawing on Arakelyan's 1968 publication in Armenian and Italian in the Armenian 
journal Pasmaveb, the Année Épigraphique produced the following entry in its 1968 volume $(A E 1968,511):{ }^{47}$

D(is) M(anibus), / C(aio) Val(erio) Cre(scenti), / mil(iti) vex(illationis) leg(ionis) I / Italice, milit(auit) / [ann(is) ... ], vics[it / ann(is) .../. . / . . ]lo, / [mile]s leg(ionis) / [VI Fer]r(atae), MILE $[\ldots b($ ene $)] m($ erenti) $p$ (osuit).

It is true that Arakelian's understanding of the text left room for improvement. Thus, restoring the cognomen of the deceased to Cre(scens) and setting his entire name to the Dative case is plausible enough. Yet other "improvements" made to Arakelian's readings (and falsely attributed to him) by the editors of the Année Épigraphique were entirely unfounded. Thus, Arakelian's photo, drawing, and commentary neither includes nor warrants the restoration of a dedicant from Syrian legio VI Ferrata, as suggested by the editors of Année Épigraphique. Apparently, they based their "improvements" on what they believed to be the remains of a single fragmentary letter, which may or may not have been an ' $R$ '. ${ }^{48}$ Moreover, their restorations leave the letters MILE, which immediately follow these traces in the second to last line of the gravestone unexplained. For such reasons, the Année Épigraphique's restoration of a dedicant from Syrian legio VI Ferrata in the lower half of the text remains wholly unconvincing. Evidently, autopsy is needed before improved readings of the traces in lines 5-9 can be suggested.

That, of course, is not to say that it is unthinkable for a soldier of legio VI Ferrata (or another legion) to have been the heir of the soldier of legio I Italica, who was buried at Artaxata during Trajan's Parthian war. This could indeed have been the case, particularly as soldiers of legio VI Ferrata were also on active campaign in Armenia in 114. However, the surviving traces on the gravestone of Gaius Valerius Crescens do not warrant the presence of this legion in Artaxata, and for all we know, C. Bruttius Praesens and his soldiers of the sixth legion fought further South in $114 .{ }^{49}$ Moreover, C. Valerius Crescens' gravestone provides no reason to assume that legio VI Ferrata remained in Greater Armenia after 114 or (as has been assumed) that it and the detachment of legio I Italica belonged to Greater Armenia's new permanent Roman garrison, as has repeatedly been claimed. ${ }^{50}$

The fact that the deceased was a soldier of a detachment of legio I Italica, which had its permanent base at Novae on the banks of the lower Danube in Moesia inferior, reflects the war-time situation. Crescens was chosen from among his fellow-soldiers of the first legion to join a combat detachment in order to fight in Trajan's Parthian War. Nothing

47 The Heidelberg epigraphic database (015524) reproduces the readings of the first four lines of l'Année Épigraphique, but not its highly speculative restorations in the lower half of the gravestone.

48 A photograph supplied by M. Zardaryan (Yerevan) does not confirm the traces to have belonged to an 'R'. It was not possible to see the fragments at the History Museum of Armenia at Yerevan in April 2018.

49 See above at note 19.

50 According to Arakelian 1968, 138, legio IV Scythica and legio I Italica (or at least a part of that legion) were the forces deployed to secure Rome's possession of Artaxata and Armenia. The editors of $A E$ 1968, 511 added legio VI Ferrata to "la garnison d'Artaxata." This was accepted by Chaumont 1976, 137. Similarly, Coloru 2013, 724. Isaac $(1992,52)$ places both Latin inscriptions from Artaxata in the period of Roman occupation after $163 \mathrm{CE}$. Wheeler $(2000,291)$ believes that Crescens' gravestone dates to $116 \mathrm{CE}$ and concludes that "the legions IV Scythica, VI Ferrata, and a vexillatio of I Italica are attested at Artaxata in 116." Strobel 2019, 439 ignores the epigraphic evidence from Artaxata altogether. 
implies that the detachment of legio I Italica was chosen to join legio IV Scythica as Artaxata's new garrison for any length of time. Yet, although it cannot be determined how long Valerius Cresens and his fellow soldiers from the vexillatio of legio I Italica stayed at Artaxata, their main task was no doubt to continue to fight in the Parthian War as part of the imperial field army. Be that as it may, Valerius Crescens' gravestone reveals one thing quite clearly: his heir (or his heirs) were firmly convinced that the Roman army would not move out of Greater Armenia again. For otherwise they would not have chosen to set up a gravestone for Crescens in Armenia. This is evidenced by the many thousand gravestones of Roman soldiers surviving from territories (in Italy, the provinces and dependent kingdoms) that were under firm and permanent Roman control, while not a single one has been found in enemy territory. ${ }^{51}$ Roman soldiers' gravestones also show a distinct tendency to cluster at garrison places or at other locations that promised to continuously attract the presence of significant numbers of soldiers. ${ }^{52}$

Although much remains uncertain, the Latin inscriptions from Artaxata, taken together, thus betray Rome's efforts to establish a permanent military center at Armenia's former royal residence.

\section{A Milestone and a Roman Road}

Another Roman infrastructure project in provincia Armenia that may have involved military resources, but that would in any event have enhanced Rome's military potential in the former kingdom is referred to in a hitherto mostly overlooked small fragment of a Latin inscription, which is now kept at the History Museum of Armenia at Yerevan. ${ }^{53}$ It was found "prope vicum Aletlu inter Igdir (ab Etschmiadzin 35 chil. ad meridiem) et Araxen ad pedem montis Ararat" and first copied by Father Galoust Ter Mkrtichian, who gave his notes to the German orientalist Carl Friedrich Lehmann-Haupt and his companion Waldemar Belck (no doubt in 1898/99 during their expedition to Armenia) with the request to pass these notes on to the editors of the Corpus Inscriptionum Latinarum (vol. III). The Latin text of this inscription was then first published in 1902 in the Supplement to CIL III as follows:

IMP

CAES DIVI

$1 / 1 / 1 / 1$

No indication was added as to the shape, type or the date of monument concerned. Only a few years later, the stone was taken to the museum at Edjmiadzin where Frédéric Macler, the great French scholar of Armenian studies saw and copied it in 1909. Macler included a description of the fragment in the published report of his journey through Armenia. ${ }^{54} \mathrm{He}$ was the first to recognize that the inscribed column-shaped fragment of

51 Speidel 2015, 245.

52 Cf. e.g. AE 1993, 1572: . . . (h)oris / noctis II defu(n)ctus / Aegeas cuius corpus / conditum Catabolo / titulum positum Apam(e)/ae ab Aurelio Mucazano h/erede b(e)ne merenti fecit; Speidel, loc. cit.

53 CIL III 13627a. It was not possible to see the inscription at the museum in Yerevan in April 2018.

54 Macler 1910, 64-65. 
white lime stone was part of a milestone, but he apparently had no knowledge of its publication in the $C I L .{ }^{55}$ Unfortunately, he provided no information concerning the find spot or the date.

Kamilla Trever, who knew the edition in the CIL but not Macler's, inspected the fragment and speculated it may have been an inscribed pillar-shaped monument or from a colonnaded building. ${ }^{56}$ Most importantly, however, she published the only photograph of this inscription to date. The fragment was later transferred to the History Museum of Armenia in Yerevan, where Timothy Mitford took a photograph and a squeeze in $1965 .{ }^{57}$ Mitford, aware of all relevant editions and literature, also recognized that the fragment belonged to a Roman milestone and maintained in his 2018 publication that "the tops of two serifs can be discerned below C, and of a third serif below the vertical stroke of D." 58 More lines, of course, once stood on the milestone, but Trever's photo does not show the remains to which Mitford referred..$^{59}$ Autopsy and more photographs are needed. ${ }^{60}$ Mitford records the name of the village where the inscription was found as "Aletli," contrary to the earlier publications that called it "Aletlu."

Despite all this, the reliable published data regarding this inscription does provide substantial historical information. Thus, this milestone can be safely dated to the period in which Armenia was a Roman province (i.e. between 114 and $117 \mathrm{CE}$ ), as there is not a single known Roman milestone that was erected beyond provincial territory. ${ }^{62}$ Other Latin texts from this period on milestones and building inscriptions can now be used as guides to restore more of the very formulaic imperial titulature (exempli gratia): ${ }^{63}$

55 The photograph published in Trever 1953, fig 81 shows that Macler's reading Imp. / Caes(ar) [M. A] $u[r \ldots] / \ldots \ldots \ldots \ldots \ldots$ is inferior to that in CIL.

56 Trever 1953, 223-224.

57 Mitford 2018, 552 no. 105. According to Mitford, the fragment was last used as a "roof roller."

58 Arakelian 1968, 139 also recognized that this was the fragment of a Roman milestone.

59 Unfortunately, Mitford did not include in his 2018 publication the photographs of the stone or of the squeeze he took in 1965. Yet he was so kind as to send me a scan of his photograph in 2018. Unfortunately, this picture also doesn't unequivocally show the traces he referred to. The fragment is missing from David French's monumental collection of milestones from Asia Minor.

60 The 'Epigraphische Datenbank Clauss / Slaby' (EDCS-73800032) offers the readings published in CIL, adding the indication "miliaria" although without reference to the source of this information. In other respects, this entry adds further confusion, for the indication of the find spot in EDCS, Iğdir, is entirely imaginary and does not lie in ancient Cappadocia, as the entry claims, but in ancient Armenia. Wheeler 2000, 300 connects the fragment with the presence of a detachment of legio XV Apollinaris at Kainepolis under Commodus. As Armenia was not a Roman province in these years, he concludes that the fragment cannot have been part of a milestone.

${ }_{61}$ Arakelian 1968, 139 calls the find spot a "villagio ora denominato Aletlou."

62 Contra: Mitford 2018, 552 suggesting to date the milestone in the "context of the Kainepolis inscriptions" (i.e. in the $160 \mathrm{~s}-180 \mathrm{~s}$ CE) when Armenia was occupied by Rome but not provincialized. Similarly, Crow 1986, 78 and 81. Similary, Isaacs 1992, 52 also calls it "a milestone from Commodus." Trever 1953, 224 dated the inscription to the period from the 1st to 3rd century CE. The pronouncements of Arakelian 1968, 139 are confusing. His reading "IMP[ERATOR] CAESAR DIVI[NUS]" and his comment "che il «divino caesare imperator» ivi menzionato, altri non sia che lo stesso Trajano" appears to imply that he considered the milestone to have been erected after Trajan's death. On the other hand, he maintained on the same page that this fragment dated to the same Trajanic period as the two Latin inscriptions from Pokr Vedi.

63 In particular, one might compare the milestone to one from near Singara in Northern Mesopotamia, that was set up not much later during the same campaign: $A E$ 1927, 161 (cf. below note 67). 


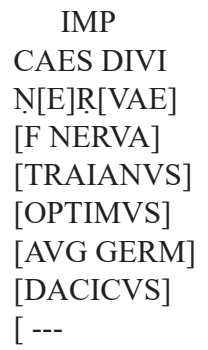

The find spot is unknown to modern and accessible ancient charts, but can be found under its alternative name Adatli or Adetli both on Russian imperial and modern maps (including 'Google maps') precisely where we would expect to find the village of Aletlu according to the $C I L$, i.e. around 35 kilometers to the South of Echmiadzin, on the foothills of Mt Ararat between Iğdir and the Arax river.

Thus, we can be certain that our milestone stood on a road that led along the northern slopes of Mt Ararat to Artaxata and legio IV Scythica's new military fortress (?). The key to understanding the position of Adetli (and of our milestone) in the network of Roman roads comes from Manandian's identification in 1965 of Paracata on the Peutinger Map (TP 10 a 4) with Bulakbaş1 on the northern foothills of Mt Ararat, just South of Taşburun. ${ }^{64}$ This is apparently also the site of a significant Uratarian fortress (which points to the old age of this route). Ruben Hakobyan, in his recent study on ancient routes in Armenia, confirmed Manandian's identification of Paracata with Bulakbaş1. ${ }^{65}$ If true, and if the fragment was not moved many kilometers from the place where it originally stood (for which there is no indication), the milestone's find spot at or near Adetli indicates that it stood on the road connecting Paracata / Bulakbaşı and Artaxata. This was the final stretch of the main road (known from the Peutinger Map) leading from the legionary base of Satala to Artaxata. According to Hakobyan, this route ran through Erzurum, the Pasin plain and vaguely followed the South bank of the Araxes from Köprüköy (Datamissa) via Horasan (Ad Confluentes), Karakurt (Barantea), Denizgölü (Andaga), Kağızman (Chadas), Karakale (Hariza), Iğdır (Coloceia) and Bulakbaşı (Paracata) to Artaxata ${ }^{66}$ This small fragment of a milestone thus illustrates that the Roman occupiers, like elsewhere, lost no time in integrating the new province into the existing network of Roman roads, which, after all, was foremost a military measure of great symbolic import at this early stage of occupation. Similarly, only some months later, a Roman road with milestones was also constructed in the new Trajanic province of Mesopotamia. ${ }^{67}$ Considering the relatively close vicinity of Artaxata to Adetli, it would not at all be surprising to find legio IV Scythica involved in this construction project.

64 Manandian 1965, 91-94. Cf. Sinclair 1987, I: 407-410.

65 Hakobyan 2016, 79.

66 Hakobyan 2016, 96-97. The route did not directly lead to Edjmiadzin, pace Mitford 2018, 552.

67 Cf. $A E$ 1927, 161 (a milestone from near Singara): Imp(erator) Caes(ar) [di]vi / Nervae f[i]l(ius) Nerva / Traianus Optimus / Aug(ustus) G[er]manicus / Dacicus [Pa]rthicus / pontif(ex) [max(imus) t] rib(unicia) $[$ potes] / [tate --- 
Taken together, the epigraphic material related to the Roman take-over of Greater Armenia, although surviving only in exceedingly small numbers, reveals Rome's determination to lose no time with establishing provincial government and Roman-style infrastructure in the new province. It is worth noting that all inscriptions, which so far can be associated with provincia Armenia are in Latin. Whether stamped bricks and tiles, monumental inscriptions or a private gravestone, they were all clear expressions of Roman imperial power. Rome evidently invested major resources into her new province between 114 and $117 \mathrm{CE}$, but at the same time this amounted to putting the traditional and proven infrastructure into place that Rome needed to control the exploitation of Greater Armenia's resources. Rome's Armenian project ended in catastrophic failure, but the Latin inscriptions discussed here show that as long as it lasted the Romans forcefully advanced the integration of the new province into the structures and fabrics of the Roman Empire.

\section{BIBLIOGRAPHY}

Albustanlığlu, T. (2015), Zeugma (Arulis/Ehneş) Taş Ocaklarında İsmi Belirlenen Bir Başka Lejyon: LEGIO IIII FLAVIA FELIX, Anadolu 41: 135-158.

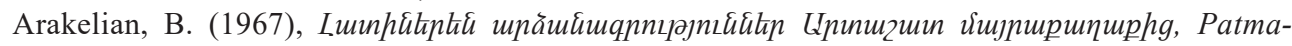
banasirakan handes 4: 302-311.

Arakelian, B. (1968), Epigrafi latine nella capitale Artašat, Pazmaveb 126: 135-139.

Arakelian, B. (1971), Latinskie nadpisi iz stolicy drevnej Armenii [Latin Inscriptions from the Capital of Ancient Armenia, Artaxata], Vestnik drevnej istorii 118(4): 114-118.

Birley, A. R. (1997), Hadrian: The Restless Emperor, London.

Birley, A. R. (2005), The Roman Government of Britain, Oxford.

Chaumont, M.-L. (1976), L'Arménie entre Rome et l'Iran I: de l'avènement d'Auguste à l'avènement de Dioclétien, $A N R W$ 2.9.1: 71-194.

Coloru, O. (2013), Armenia, in: R. Bagnall et al. (eds.), The Encyclopedia of Ancient History, vol. 1, Oxford: 722-725.

Cotton, H., Eck, W., (1999), Ein Statthalter von Syria Palaestina unter Marc Aurel und Lucius Verus in einer Bauinschrift aus Jericho, ZPE 127: 211-215.

Crow, J. (1986), a Review of the Physical Remains of the Frontiers of Cappadocia, in: P. Freeman, D. Kennedy (eds.), The Defence of the Roman and Byzantine East, Oxford: 77-91.

Devijver, H. (1998), Commanders and Officers of Legio IIII Scythica, in: D. Kennedy (ed.), The Twin Towns of Zeugma on the Euphrates: Rescue Work and Historical Studies, Portsmouth, RI: 205-232.

Dietz, K., Fischer, T. (2018), Regensburg zur Römerzeit. Von Roms nördlichster Garnison an der Donau zur ersten bairischen Hauptstadt, Regensburg.

Eck, W. (1982), Jahres- und Provinzialfasten der senatorischen Statthalter von 69/70 bis 138/139, Chiron 12: 281-362.

Glodariu, I. (1966), Legio IV Flavia Felix in Dacia, Acta Musei Napocensis 3: 429-435.

Hakobyan (Tarumian), R. (2016), Armenia Viae. Antique itinera Armeniae generale et vicinarumque regionum secundum tabula Peutingeriana, Yerevan.

Horster, M. (2001), Bauinschriften römischer Kaiser. Untersuchungen zu Inschriftenpraxis und Bautätigkeit in Städten des westlichen Imperium Romanum in der Zeit des Prinzipats, Stuttgart. 
Isaac, B. (1992), The Limits of Empire: The Roman Army in the East, 2nd edition, Oxford.

Kanetsian, A. (1998), Città e insediamenti nell'Armenia di età classica, in: A. Invernizzi (ed.), Ai piedi del' Ararat. Artaxata e l'Armenia ellenistico-romana, Firenze: 3-89.

Khachatryan, Z. (2006), Tiles and Bricks with Stamps Bearing Latin Inscriptions Found in Artashat, Istoriko-filologiceskij zurnal 171(1): 230-235.

Kienast, D. (2017), Römische Kaisertabelle. Grundzüge einer römischen Kaiserchronologie, 6th revised edition by W. Eck and M. Heil, Darmstadt.

Lichtenberger, A., Zardaryan, M., Schreiber, T. (2020), The Armenian-German Artaxata Project: Preliminary Report on the Excavations in Artashat 2019, AJNES 14: 184-227.

Macler, F. (1910), Rapport sur une mission scientifique en Arménie russe et en Arménie turque (juilletoctobre 1909), Nouvelles Archives des Missions Scientifiques et Littéraires, n. s. 18.2: 1-180.

Manandian, H. A. (1965), The Trade and Cities of Armenia in Relation to Ancient World Trade, Lisboa.

Marciak, M. (2017), Sophene, Gordyene, Adiabene: Three regna minora of Northern Mesopotamia between East and West, Leiden.

Mitford, T. B. (1974), Some Inscriptions from the Cappadocian Limes, JRS 64: 160-175.

Mitford, T. B. (2018), East of Asia Minor, 2 vols., Oxford.

Pflaum, H.-G. (1960-1961), Les carrières procuratoriennes équestres sous le Haut-Empire romain, 3 vols., Paris

Piso, I. (2000), Les légions dans la province de Dacie, in: Y. Le Bohec, C. Wolff (eds.), Les légions de Rome sous le Haut-Empire, vol. 1, Paris: 205-226.

Reynolds, J. (1971), Roman Inscriptions 1966-1970, JRS 61: 136-152.

Sinclair, T. A. (1987), Eastern Turkey: An Architectural and Archaeological Survey, vol. 1, London.

Speidel, M. A. (1998), Legio IIII Scythica, Its Movements and Men, in: D. Kennedy (ed.), The Twin Towns of Zeugma on the Euphrates: Rescue Work and Historical Studies, Portsmouth, RI: 163-204.

Speidel, M. A. (2009), Heer und Herrschaft im Römischen Reich der Hohen Kaiserzeit, Stuttgart.

Speidel, M. A. (2015), 'Almaqah in Rom? Zu den Beziehungen zwischen dem kaiserzeitlichen Imperium Romanum und Südarabien im Spiegel der dokumentarischen Überlieferung, ZPE 194: 241-258.

Speidel, M. A. (forthcoming), Trajan and the Red Sea, in: M. Sayar (ed.), The Roman Emperor Marcus Ulpius Traianus.

Strobel, K. (2019), Kaiser Traian. Eine Epoche der Weltgeschichte, 2nd edition, Regensburg.

Syme, R. (1969), Legates of Cilicia under Trajan, Historia 18: 352-366.

T'arumean (Yakobean), R. (2014-2016), Hayk'i čanaparhnerz. Onthanur Hayk'i ew harakic ‘ tarack'neri hnašxarhik utinern ast Pewtingerean k'artezi [The Roads of Hayk'. The Itineraries of General Armenia and of the Neighbouring Regions According to the Peutinger Map], Erevan.

Trever, K. (1953), Očerki po istorii kul'tury drevnej Armenii [Essays on the Cultural History of Ancient Armenia], Moskva-Leningrad.

Wheeler, E. (2000), Legio XV Apollinaris: From Carnuntum to Satala — and beyond, in: Y. Le Bohec, C. Wolff (eds.), Les légions de Rome sous le Haut-Empire, vol. 1, Paris: 258-308.

Xač‘atryan, Ž. (2006), Artašatic ' haytnabervac latineren arjanagrut'yamb drošmvac ew ałyusner [Tiles and Bricks with Stamps Bearing Latin Inscriptions Found in Artaxata], Patma-banasirakan handes 171.1: 230-235. 